\title{
Screening of Antifungal Activities of Five Algal Crude Extracts
}

\section{HanahemAlfetoryMusbah $^{5}$, Wafaa Sobhi Abouelkhair ${ }^{1}$,ShymaaAbd Elkader Yousef ${ }^{2}$, Elham Elsaid Moustafa ${ }^{3}$, and Amr Mahmoud Helal Hasan ${ }^{4}$.}

1- Prof. of Phycology , Botany Department, Women's Faculty for Arts, Science and Education, Ain Shams University.

2- Lecturer in Phycology, Botany Department, Women's Faculty for Arts, Science and Education, Ain Shams University.

3- Lecturer in Microbiology, Botany Department, Women's Faculty for Arts, Science and Education, Ain Shams University.

4- Research in the National Institute Oceanography and Fisheries.

\begin{abstract}
:
In the present study, four species of marine algae were collected during different seasons for one year (September 2013 to August 2014). The collected species belonged to Chlorophyta (Ulva lactuca), Phaeophyta (Sargassum denticulatum, Hormophysa triquetra) and Rhodophyta (Hypnea cornuta) in addition to one blue- green alga from freshwater (Spirulina platensis) was obtained from stock at Hydrobiology Lab, Qanater, Khayria, Qalubia, Egypt. Crude algal extracts were prepared by using different solvents (methanol, ethanol and chloroform) in addition to hot water and cold water extracts. The crude algal extracts were examined for their antifungal efficacy against oral Candida species (Candida albicans, C.tropicalis, $\quad$ C.krusei and C.glabrata) using agar well diffusion method. Results revealed that methanol was the best solvent suited for extraction of bioactive compounds from the tested algae. Chlorophyta (ulva lactuca) exhibited the highest antifungal effect followed by Phaeophyta, Rhodophyta and blue green algae. MIC of the most potent algal (ulva lactuca) methanol extract was $62.5 \mathrm{mg} / \mathrm{ml}$ and MFC was $125 \mathrm{mg} / \mathrm{ml}$ for the same alga with all the tested oral Candida species. (comparison was made between MFC value of Ulva lactuca methanol extract with the anti chlorhexidine $(0.1 \mathrm{mg} / \mathrm{ml})$ (which is a common antimicrobial agents in commercialized oral rinses). by using (PIDG). The results shown that the Ulva lactuca methanol extract better than PIDG of chlorhexidine.
\end{abstract}

Keywords: Marine algae, Antifungal activity, Solvent extracts, Oral Candida species, (MIC) and (MFC).

\section{Introduction:}

Algal extracts contain compounds such as carbohydrates, proteins, minerals, oil, fats, polyunsaturated fatty acids as well as bioactive compounds such as antioxidants (polyphenols, tocopherols, vitamin E, vitamin C. mycosporine-like amino acids), pigments, such as carotenoids (carotene xanthophylls) cholorophylls, and phycobilins (phycocyanin, phycoerythrin), which possess antibacterial, antiviral, antifungal, antioxidative, anti-inflammatory and antitumor properties (Harun et al., 2014). Recently, there is increased interest in naturally produced active compounds as alternatives to synthetic substances. Although these compounds often show lower activity, they are nontoxic and do not leave residues. This implies that there is a 
need to develop new and safe products of biological origin, with properties similar to the synthetic, in particular antimicrobial, antifungal, antioxidizing compounds and colorants. These natural compounds are found in algal extracts (Michalak and Chojnacka 2014). Oral candidiasis is an opportunistic infection of the oral cavity caused by the overgrowth of Candida species, usually of $C$. albicans. Candida species are present as commensal organisms of the oral micro biota in about 20-60\% of normal human population (Aggarual $\boldsymbol{e t}$ al., 2018). The genus Candida belongs to yeasts. It is also the most common cause of opportunistic mycoses worldwide. It is a frequent colonizer of human skin and mucous membranes (Greenberg \& Burket's, 2005).

Although pharmaceutical industries have produced a number of new antimicrobial drugs in the last few years, resistance to these drugs by microorganisms has increased rapidly (El bashiti et al., 2011). While natural products have traditionally been harvested from terrestrial sources such as soil and higher plants, reports show that marine organisms are rich sources of structurally new and biologically active metabolites. Approximately 16,000 marine natural products have been isolated from marine organisms and reported in approximately 6,800 publications. Some of these compounds are unique to marine organisms (Bhakuni $\&$ Rawat, 2005). According to Smit, 2004 the discovery of metabolites with biological activity from algae increased substantially in the last three decades. These substances exhibit an appreciable number of distinct biological activities such as antitumor, antiviral, antifungal, insecticidal, cytotoxic, phytotoxic and antiproliferative actions (Machado et al., 2010). The majority of these compounds are terpenes and polyphenols (Blunt et al., 2006). Osman et al. (2013) studied the antimicrobial activity of three different macroalgal species belonging to Rhodophyta, Chlorophyta and Phaeophyceae, respectively (Janiarubens, Ulva fasciata and Sargassum vulgare) were collected seasonally in 2007 to 2008 from Abu-Qir bay (Alexandria, Egypt). The different macroalgal species were tested against pathogenic microbes such as Bacillus subtilis, Staphylococcus aureus and Streptococcus aureusas gram-positive bacteria, Escherichia coli, Salmonella typhi and Klebsiella pneumonia as gram-negative bacteria and one yeast strain Candida albicans. Shobier et al. (2016) studied the antifungal activity and the chemical constituents of selected macroalgae collected from the Egyptian Mediterranean coast of Alexandria have been investigated against Fusarium solani, Fusarium oxysporum, Tricoderma hamatum, Aspergillus flavipes and Candida albicans. Sheikh et al. (2018) evaluated the antimycotic activity of fifteen species of the dominant marine algae were collected during summer 2013 from four selected sites on Red sea coast, Jeddah, Saudi Arabia. The collected species belonged to Chlorophyta, Phaeophyta and Rhodophyta. The crude algal extracts were examined for their antifungal efficacy against Aspergillus flavus, Aspergillus fumigatus, Aspergillus niger, Candida albicans and Candida tropicalis.

The present study aimed to detect the effect of some algal extracts for four marine macroalgal Ulva lactuca (green algae), Sargassum denticulatum and Hormophysa triquetra (brown algae) and Hypnea cornuta (red algae), also one fresh water blue-green alga (Spirulina platensis) on the growth of some oral Candida species (Candida albicans, Candida tropicalis, Candida krousei and Candida glabrata) Also determination of the minimum inhibitory concentration (MIC), minimum fungicidal concentration (MFC) against the four oral Candida $s p$ and the percentage inhibition of diameter growth (PIDG) for the fungal pathogen tested oral Candida $s p$. 


\section{Materials and Methods:}

\section{Identification of algae:}

A-Fresh water alga:

Spirulina platensis ( Nords, Geitler ).

B- Marine algae:

The identification was done according to Papenfuss (1989) .Ulva lactuca (Linnaeus) (Chlorophyceae), Sargassum denticulatum (BØrgesen) (Phaeophyceae) and Hypnea cornuta (Rayss and Dor) (Rhodophyceae) and Hormophysa triquetra (Kütizing) (Phaeophyceae).

\section{Sampling program:}

A-Fresh water alga (Spirulina platensis):

The tested blue green alga Spirulina platensis was obtained from Stock at Hydrobiology Lab, Qanater Khayria, Qalubia, Egypt.

B- Marine algae:

Seaweeds were collected seasonally for one year (September 2013 to August 2014) from the intertidal zone of the Gulf of Suez. Three algal samples: Ulva lactuca (Chlorophyceae) during spring, Sargassum denticulatum (Phaeophyceae) during autumn and Hypnea cornuta (Rhodophyceae) during winter were taken from Site I (Ras El-Adabiya ) and one algal sample from Site II (RasSedr) Hormophysa triquetra (Phaeophyceae) during summer.

\section{Sampling collection:}

Seaweeds, were carefully washed by seawater, collected in plastic bags and kept in an ice - box at $20^{\circ} \mathrm{C}$. The frozen seaweeds were lift to thaw and washed with distilled water to get rid of salts then lift to dry in indirect light. After dryness the samples were grinded for further analysis.

\section{Preparation of the algal extracts :}

Extraction of the ground algal powder were done using different solvents such as methanol, ethanol and chloroform (separately). Twenty-five grams of each algal powder sample were soaked in $100 \mathrm{ml}$ of each solvent for $24 \mathrm{~h}$ (separately) on a rotator shaker at $150 \mathrm{rpm}$ at room temperature $\left(25^{\circ} \mathrm{C}: 30^{\circ} \mathrm{C}\right)$. The resultant crude extracts were filtered through whatman filter paper no (1).The filtrate was freed from solvent by evaporation under reduced pressure by rotary evaporator Then the obtained residues (crude extracts)were separately suspended in 10\%Dimethylsulfoxide (DMSO) to obtain $100 \mathrm{mg} / \mathrm{ml}$. Each extract was stored at $-20^{\circ} \mathrm{C}$ in airtighted glass bottle for the antimicrobial assay (Cho et al., 2007).

A- Hot water extract (Subash et al., 2010).

- One hundred gram of powder for each algae was extracted separately with $300 \mathrm{ml}$ of distilled water $\left(90-95^{\circ} \mathrm{C}\right)$ for $3 \mathrm{hr}$.The coloured syrup was filtered through whatman no. 3 paper. then concentrated to $1 / 4$ th of the original volume.

- After that it was cooled and precipitated with $100 \mathrm{ml}$ of ethanol.

- The precipitate was collected by centrifugation for $30 \mathrm{~min}$, dehydrated with diethyl ether and dried at $37^{\circ} \mathrm{C}$ until diethyl ether free.

- Finally $30 \mathrm{ml}$ ethyl acetate was added to the filter and take the residue. 


\section{B- Cold water extract (Subash et al.2010).}

- The same procedure without heating but the 100 gram of powder for each algae(separately) was soaked with $300 \mathrm{ml}$ of distilled water at $4^{\circ} \mathrm{Cover}$ night.

- The coloured syrup was filtered through whatman no.3 paper. then it was precipitated with $100 \mathrm{ml}$ of ethanol.

- The precipitate was collected by centrifugation for $30 \mathrm{~min}$, dehydrated with diethyl ether and then dried at $37^{\circ} \mathrm{C}$ until diethyl ether free.

- Finally $30 \mathrm{ml}$ ethyl acetate was added to the filter and take the residue.

\section{Microorganism:}

\section{The source of Candida isolates:}

\section{Oral Candida isolates:}

Candida species used in this study were isolated from oral cavity of diabetic patients from AlAzhar hospital.

\section{Cultivation of oral Candida species and growth condition:}

Four oral Candida species were employed as test organism which included Candida albicans, Candida tropicalis, Candida krusei and Candida glabrata.

\section{Sabouraud Dextrose Agar (SDA):}

This medium was used for cultivation and growth of Candida; it contains (gram/liter)

- 40 Dextrose

- 10 Peptone

- 20 Agar

- 1 Distilled water

The $\mathrm{pH}$ of the medium was adjusted at $5.6 \pm 0.1$ and sterilized by autoclaving at $121^{\circ} \mathrm{C}$ for 15 minutes.

The Candida strains were cultured on SD agar plates at $37^{\circ} \mathrm{C}$ for $48 \mathrm{hrs}$.

All strains were maintained on SD agar and subcultured monthly.

\section{Preparation of inoculation:}

Twenty- four hours old cultures of oral Candida species were mixed separately with SD broth medium and turbidity was adjusted using spectrometer at wave length of $600 \mathrm{~nm}$ in order to obtain absorbance O.D $\simeq 0.5$, which resulted in final concentration of $10^{8}$ CFU/ml(Colony Forming Unit).

\section{Antifungal susceptibility test:}

\section{Antifungal assay :}

In vitro the antifungal activity was screened by agar well diffusion method (Bauer $\boldsymbol{e} t$ al., 1996). Candida species inoculates $\left(10^{8}\right.$ cells $\left./ \mathrm{ml}\right)$ were spread on SD agar plates and left to dry at room temperature, wells were made on the surface of agar medium with $6 \mathrm{~mm}$ cork borer. Each well in plate was filled with $50 \mu \mathrm{m}$ of algal crude extract using micropipette. 
The plates were incubated at $37^{\circ} \mathrm{C}$ from $24-48 \mathrm{hrs}$, At the end of incubation the plates were observed for the zone of inhibition and the diameters of the zones were measured in millimeters (Karabay-Yavasoglu et al., 2007).

All assays were carried out independently in triplicates and the mean result were calculated, also Fluconazole and dimethyl sulfoxide (DMSO) were used as positive and negative controls, respectively.

\title{
Determination minimum inhibitory concentrations (MIC):
}

The minimum inhibitory concentration (MIC) was applied on the crude extracts of Ulva lactuca these proved their high effectiveness against some oral Candida species by the agar well diffusion method. It was determined by using two fold serial dilution method .

The highest dilution of an extract that still retains an inhibitory effect against the growth isolates of oral Candida sp. is known as the MIC (Misra and Dixit, 1978).

The complete protocol of the MIC test is found in the M7-T2 publication of the National Committee for Clinical Laboratory Standards (2000).

Briefly, different crude extracts preparations were subjected to a serial dilution using SD broth medium as a diluents to give final crude extract concentration between $250 \mathrm{mg} / \mathrm{ml}$ and $31.25 \mathrm{mg} / \mathrm{ml}$. The tubes were inoculated with Candida suspension $(20 \mu / \mathrm{ml}$ broth). Homogenized and incubated at $37^{\circ} \mathrm{C}$ for $24 \mathrm{~h}$. Following this, the lowest concentration of the crude extract that inhibited the visible growth of oral Candida $s p$. (absence of turbidity) was recorded as the MIC value of the crude extract.

The positive and negative controls were performed using SD broth medium. All MIC tests were performed independently for each Candida sp.

\section{Determination of minimum fungicidal concentrations(MFC):}

An overnight incubation for the MIC (determin50 $\mu$ l) of each tube which indicate no growth for all respective Candida $s p$, were sub cultured onto SD agar plates. The plates were incubated at $37^{\circ} \mathrm{C}$ for 24 to $48 \mathrm{~h}$ until visible growth was observed. The MFC value was the concentration where no growth or fewer than 3 colonies were obtained to approximately 99 :99.5 killing activity, Clinical and Laboratory Standards Institute (2002).

\section{Determination of the Percentage Inhibition of Growth Diameter (PIGD):}

The observation for MFC and the percentage inhibition of diameter growth (PIDG) values were determined according to the equation as below:

\author{
Diameter of sample - Diameter of control \\ $\operatorname{PIDG}(\%)=\stackrel{-}{-} 100$ \\ Diameter of control
}




\section{Results:}

\section{Antifungal activity:}

The data in Figs.1.2 and3 showed that:

i. Methanol extract of Spirulina platensis had an effect against Candida albicans, C. krusei and $C$. glabrata and the recorded inhibition zones were $28 \mathrm{~mm}, 27.33 \mathrm{~mm}$ and $29.67 \mathrm{~mm}$ (respectively), but no effect against $C$. tropicalis.

ii. Ethanol extract of Spirulina platensis showed an effect against Candida albicans, $C$. krusei and $C$. glabrata and the recorded inhibition zones were $25.67 \mathrm{~mm}, 20 \mathrm{~mm}$ and $20.67 \mathrm{~mm}$ (respectively), but no effect against $C$. tropicalis.

iii. Chloroform, Hot water and Cold water extracts of Spirulina platensis showed no effect against any of the tested oral Candida $s p$.

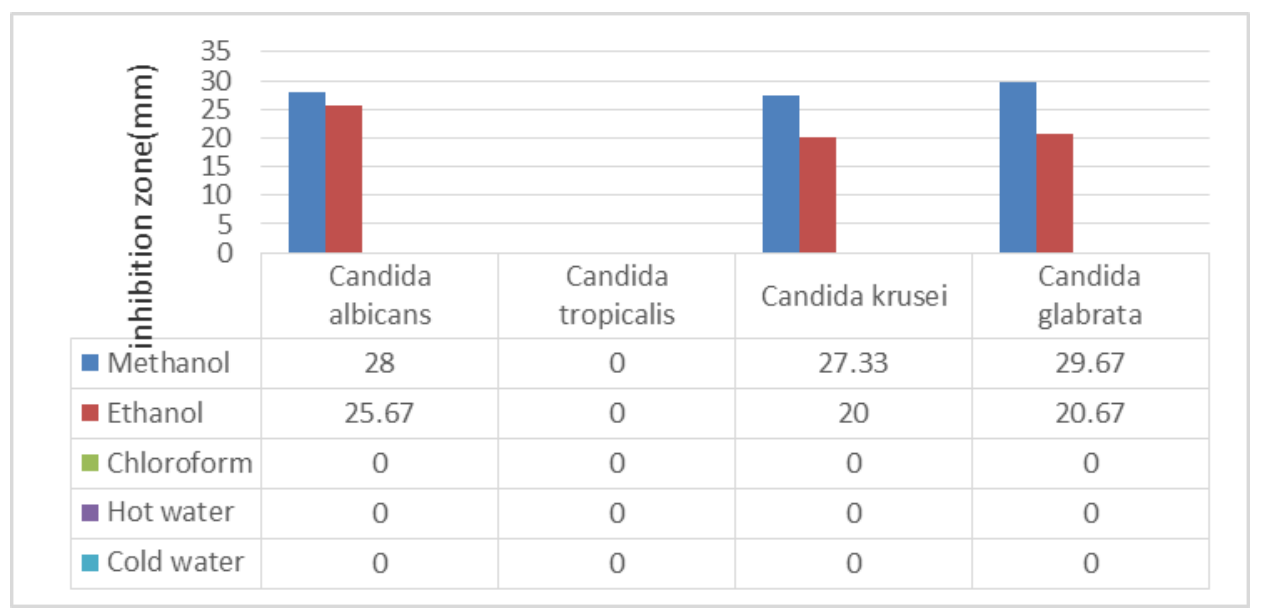

Fig. (1) : Antifungal activities of Spirulina platensis extracts against oral Candida sp.

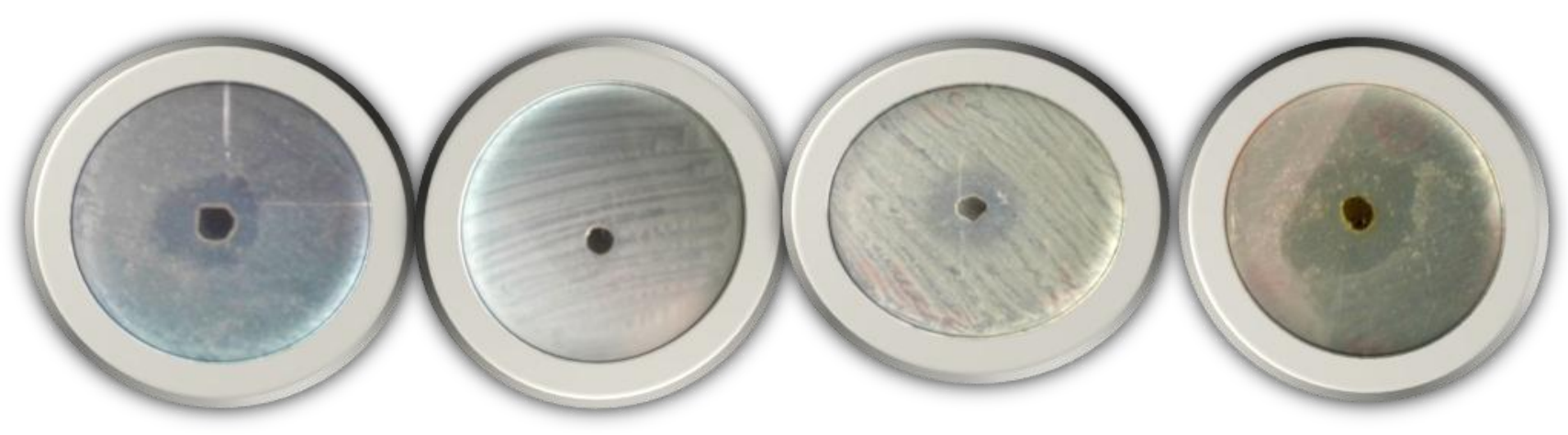

Candida albicans

Candida tropicalis

Candida krusei

Candida glabrata

Fig. (2):Antifungal activities of methanol extract for Spirulina platensis concentration $(100 \mathrm{mg} / \mathrm{ml})$ on oral Candida species growth. 


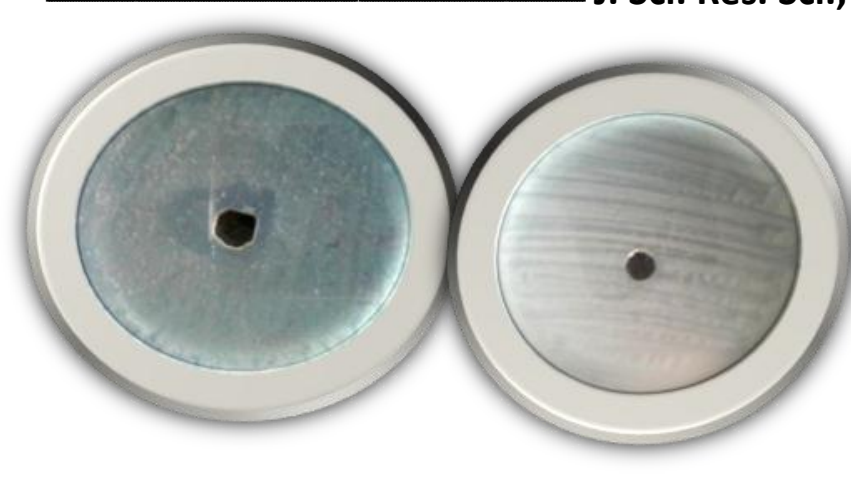

Candida all
Candida tropicalis

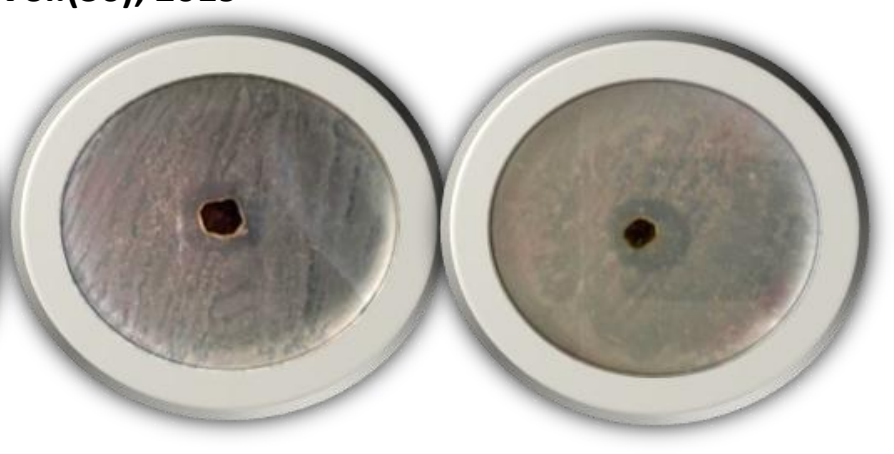

Candida krusei

Candida glabrata

Fig. (3):Antifungal activities of ethanol extract of Spirulina platensis concentration $(100 \mathrm{mg} / \mathrm{ml})$ on oral Candida species growth.

The data in Figs.4.5.6 and 7 showed that:

i. Methanol extract of Ulva lactuca had an effect against all the tested oral Candida sp. with inhibition zones of 45,35,32 and 30mm for Candida albicans, $\quad$ C. tropicalis, $C$. krusei and C. glabrata (respectively).

ii. Ethanol extract of Ulva lactuca showed an effect against Candida albicans, C. krusei and C. glabrata with inhibition zones of $26 \mathrm{~mm}, 28 \mathrm{~mm}$ and $26 \mathrm{~mm}$ (respectively). While it had no effect against $C$. tropicalis.

iii. Chloroform extract of Ulva lactuca had an effect against Candida albicans, C.tropicalis and C. glabrata with inhibition zones of $32 \mathrm{~mm}, 25.67 \mathrm{~mm}$ and $31 \mathrm{~mm}$ (respectively). While it had no effect against $C$. krusei.

iv. Hot water and Cold water extracts of Ulva lactuca showed no effect against any of the tested oral Candida sp.

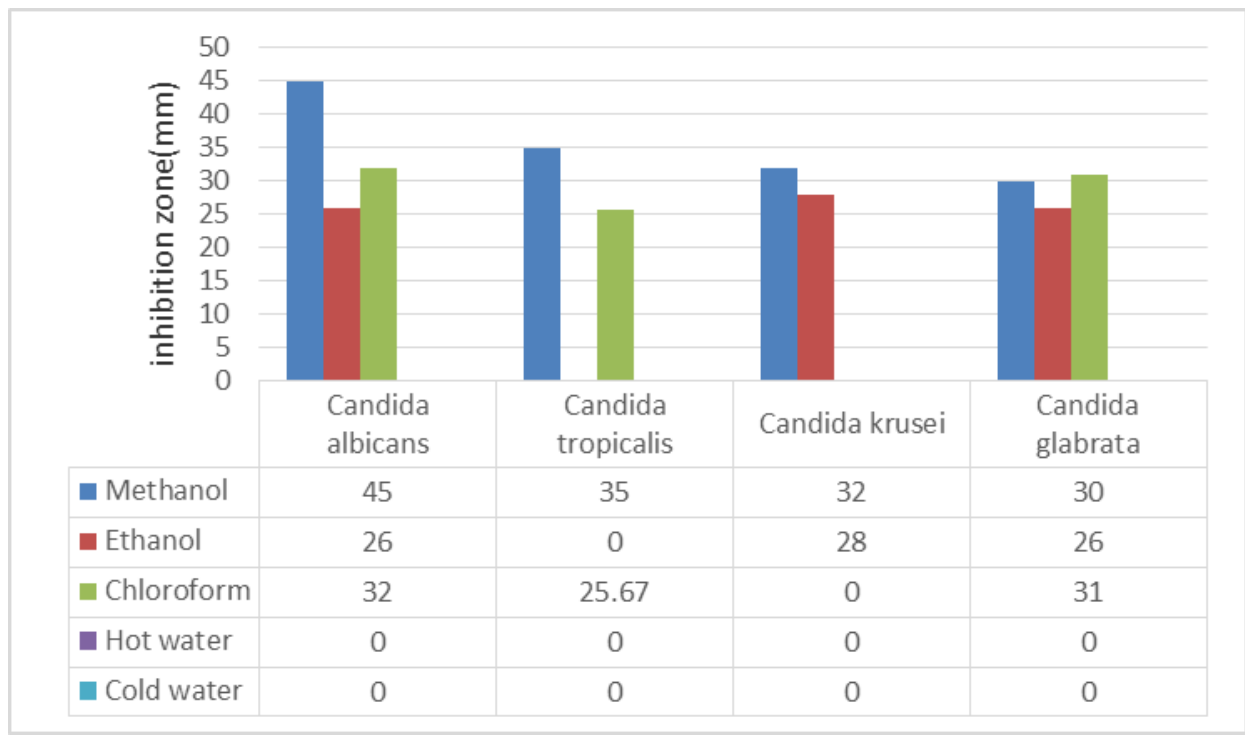

Fig. (4) : Antifungal activities of Ulva lactuca extracts against oral Candida sp. 


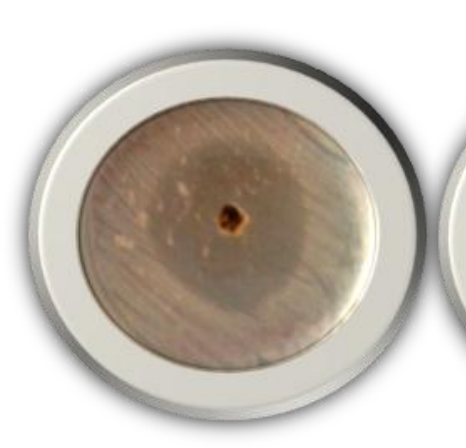

Candida albicans

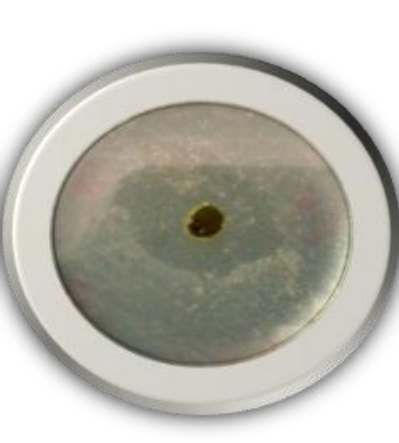

Candida tropicalis

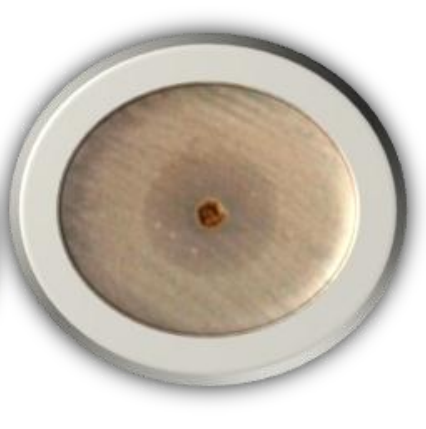

Candida krusei

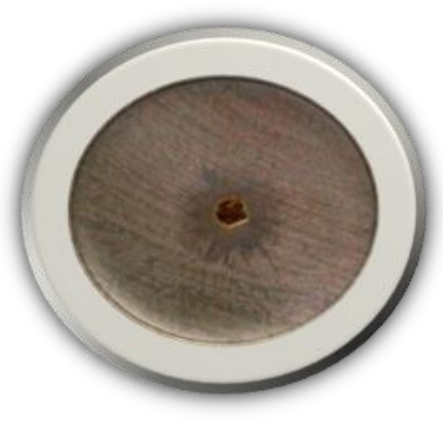

Candida glabrata

Fig. (5): Antifungal activities of methanol extract of Ulva lactuca concentration $(100 \mathrm{mg} / \mathrm{ml})$ on oral Candida species growth.

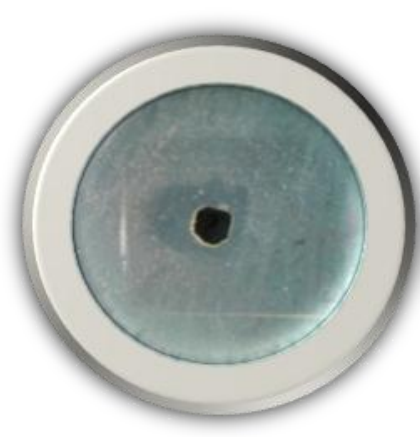

Candida albicans

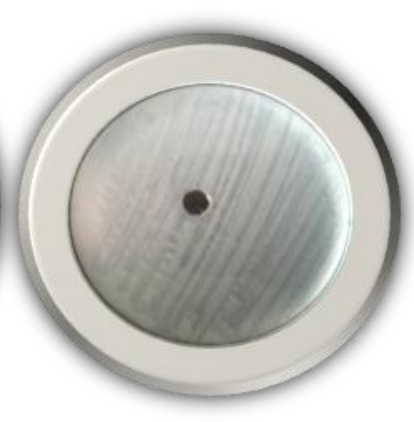

Candida tropicalis

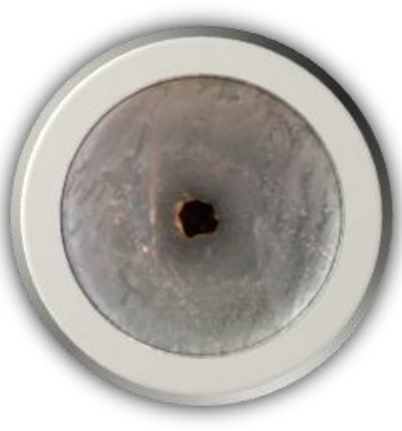

Candida krusei

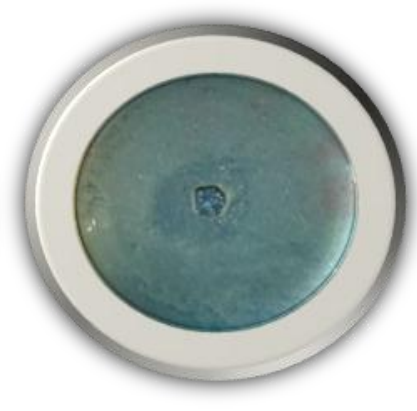

Candida glabrata

Fig. (6): Antifungal activities of ethanol extract of Ulva lactuca concentration $(100 \mathrm{mg} / \mathrm{ml})$ on oral Candida species growth

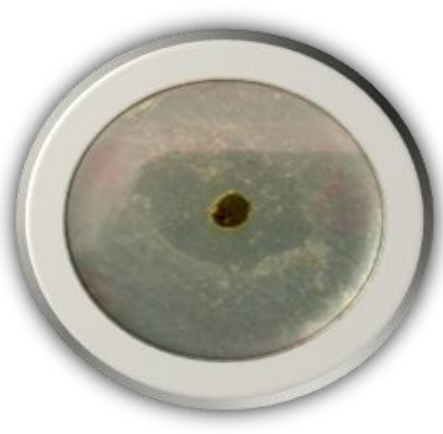

Candida albicans

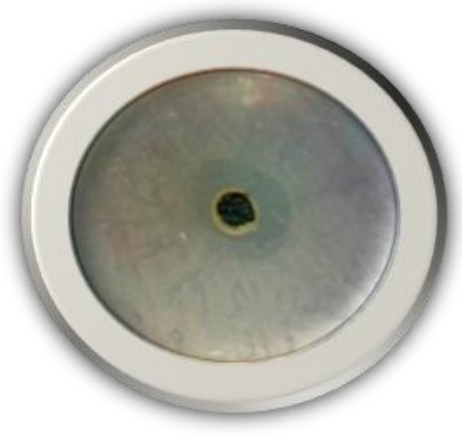

Candida tropicalis

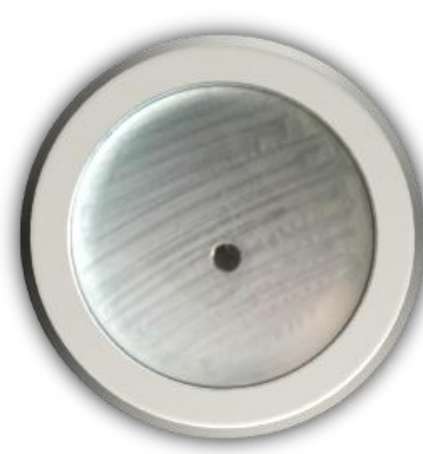

Candida krusei

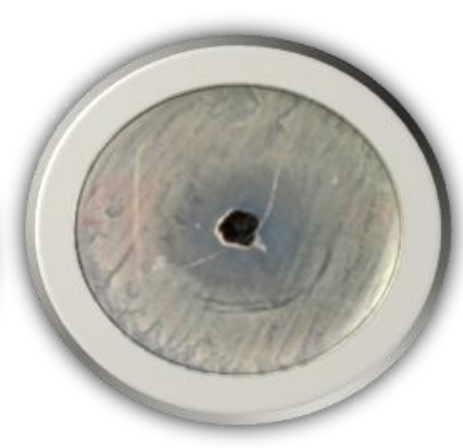

Candida glabrata

Fig. (7): Antifungal activities of chloroform extract of Ulva lactuca concentration (100mg/ml) on oral Candida species growth. 
The data in Figs.8.9 and 10 showed that:

i. Methanol extract of Sargassum denticulatum showed an effect against Candida albicans, C. tropicalis and C. glabrata with recorded inhibition zones of $21.67 \mathrm{~mm}, 22.67 \mathrm{~mm}$ and $55.33 \mathrm{~mm}$ (respectively). While it had no effect against $C$. krusei.

ii. Ethanol extract of Sargassum denticulatum had an effect against Candida albicans, $C$. tropicalis and $C$. glabrata with recorded inhibition zones of $16.33 \mathrm{~mm}, 20 \mathrm{~mm}$ and $25.67 \mathrm{~mm}$ (respectively). While it had no effect on C. krusei.

iii. Chloroform, Hot water and Cold water extracts of Sargassum denticulatum showed no effect against any of the tested oral Candida $s p$.

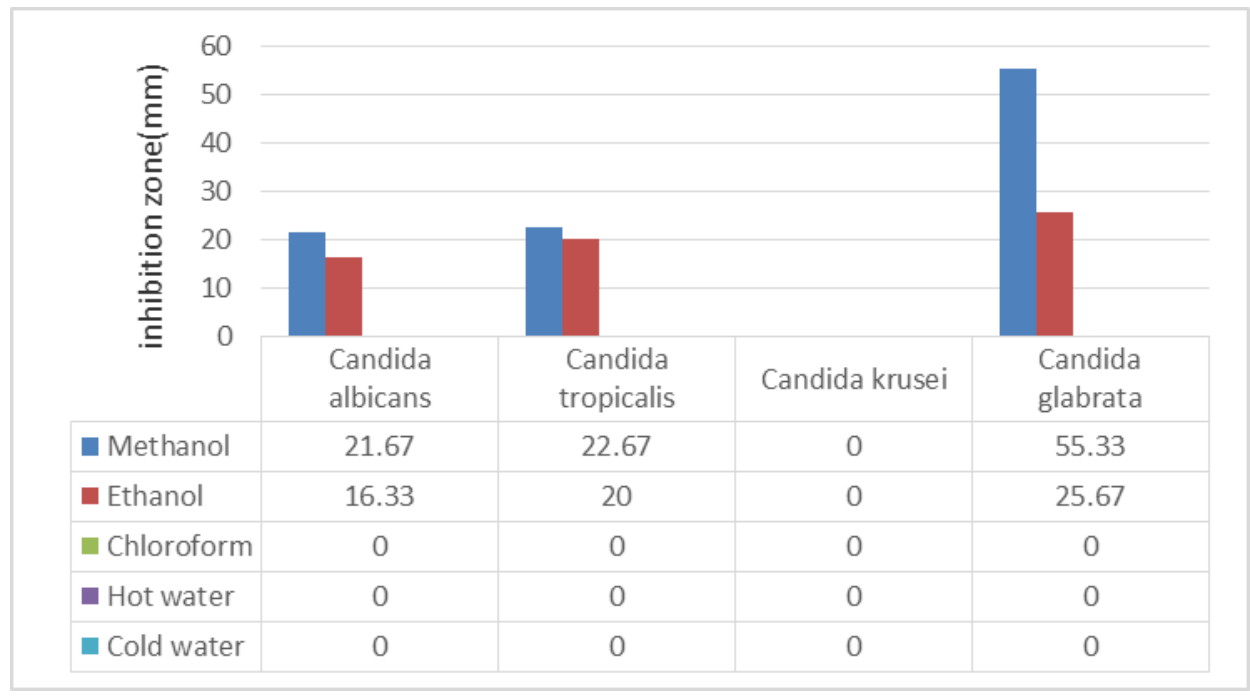

Fig. (8) : Antifungal activities of Sargassum denticulatum extracts against oral Candida sp.

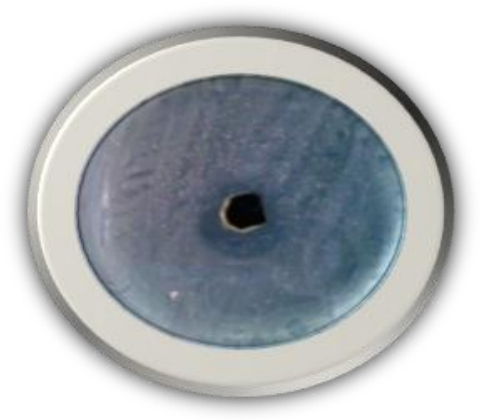

Candida albicans

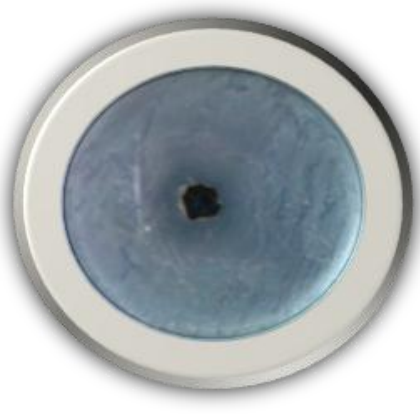

Candida tropicalis

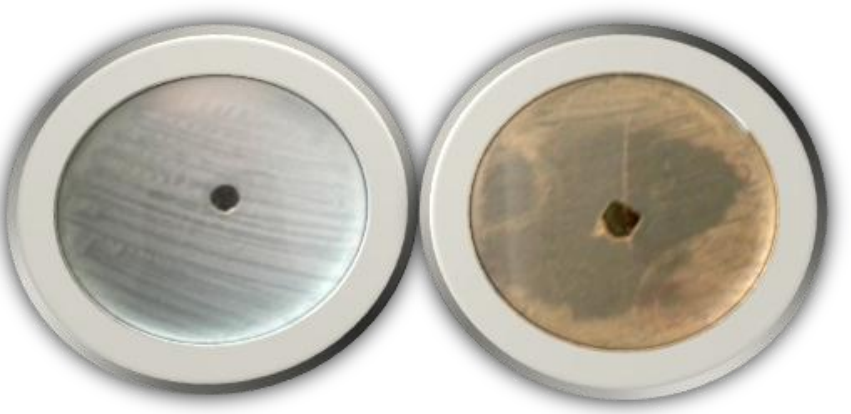

Candida krusei
Candida glabrata

Fig. (9): Antifungal activities of methanol extract of Sargassum denticulatum concentration (100mg/ml)on oral Candida species growth. 


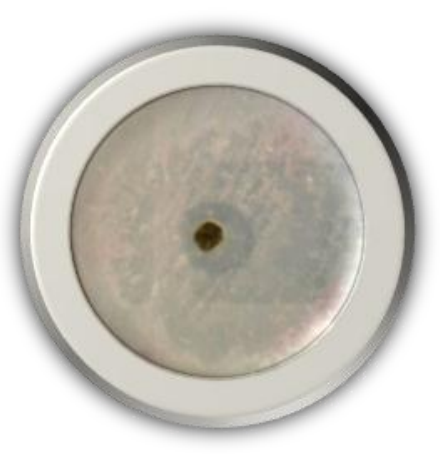

Candida albicans

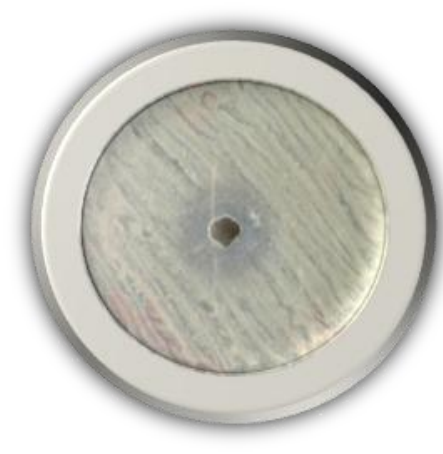

'andida tropicalis

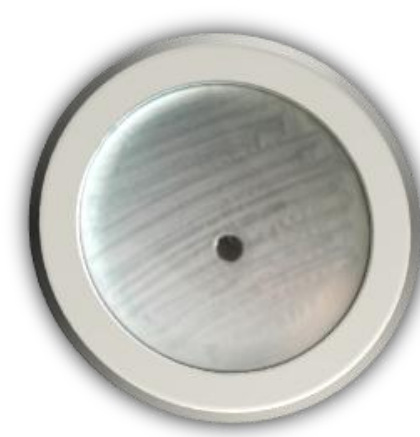

Candida krusei

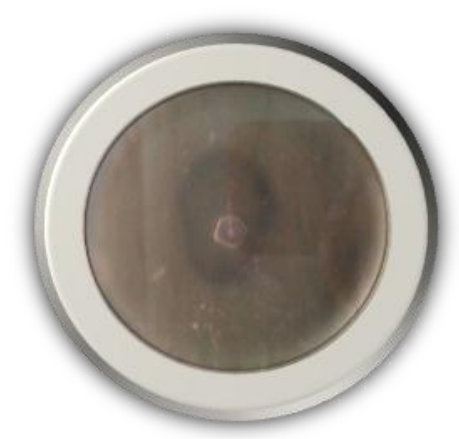

Candida glabrata

Fig. (10): Antifungal activities of ethanol extract of Sargassum denticulatum concentration $(100 \mathrm{mg} / \mathrm{ml})$ on oral Candida species growth.

The data in Figs. 11.12.and 13 showed that:

i. Methanol and Ethanol extracts of Hormophysa triquetra had an effect against Candida glabrata only with inhibition zone of 40.33 and $33.33 \mathrm{~mm}$ (respectively), but it had no effect against other tested oral Candida $s p$.

ii. Chloroform, Hot water and Cold water extracts of Hormophysa triquetra showed no effect against any of the tested oral Candida sp.

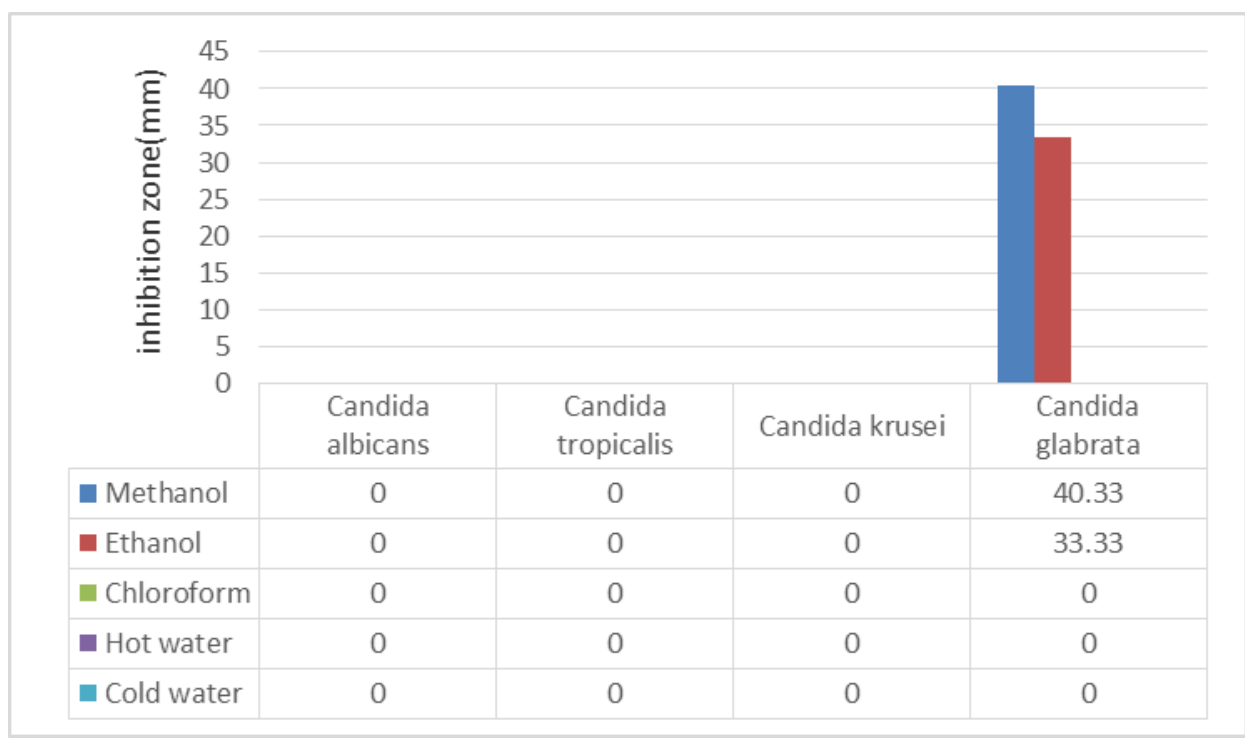

Fig. (11) : Antifungal activities of Hormophysa triquetra extracts against oral Candida sp. 


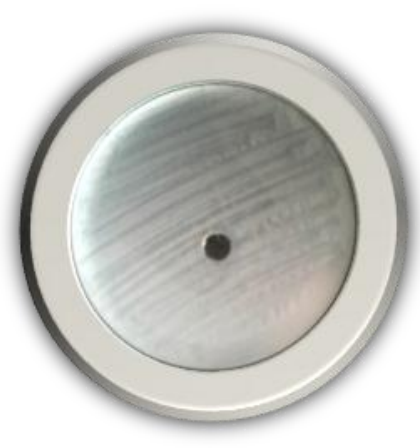

Candida albicans

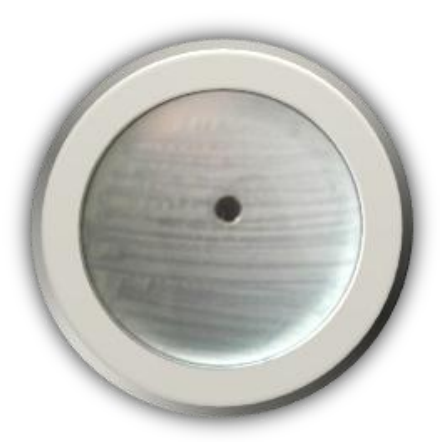

Candida tropicalis

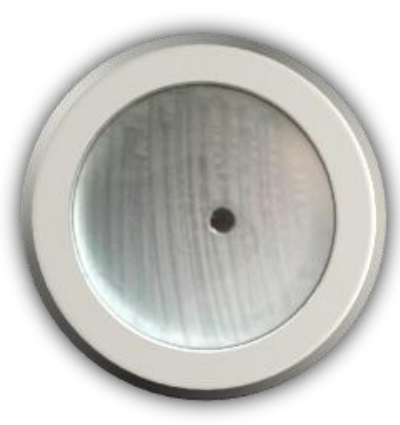

Candida krusei

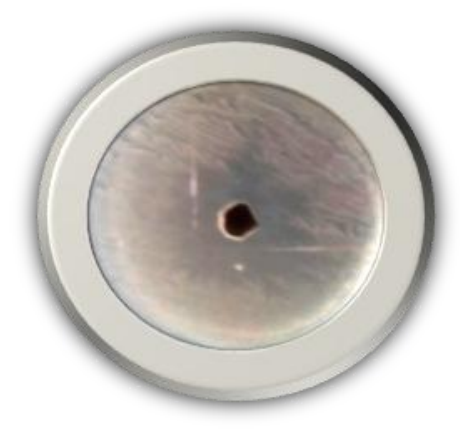

Jandida glabrata

Fig. (12): Antifungal activities of methanol extract of Hormophysa triqutra concentration $(100 \mathrm{mg} / \mathrm{ml})$ on oral Candida species growth.

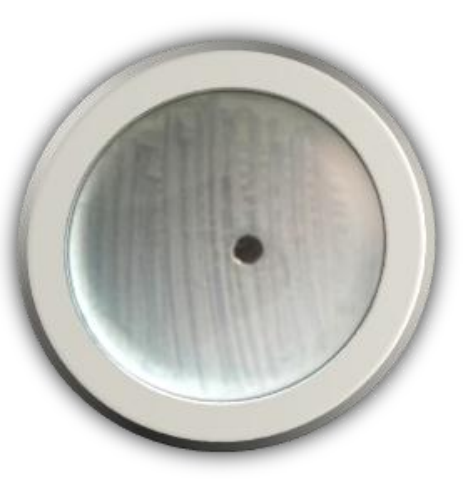

Candida albicans

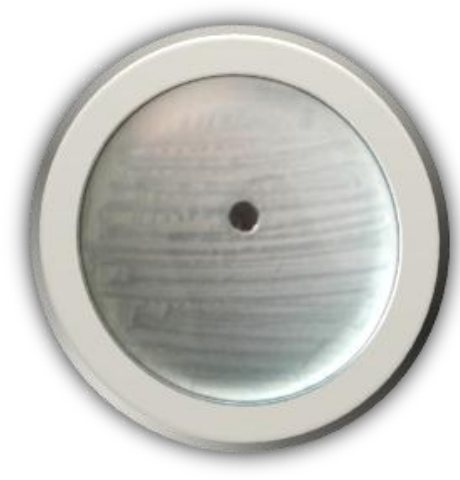

Candida tropicali:

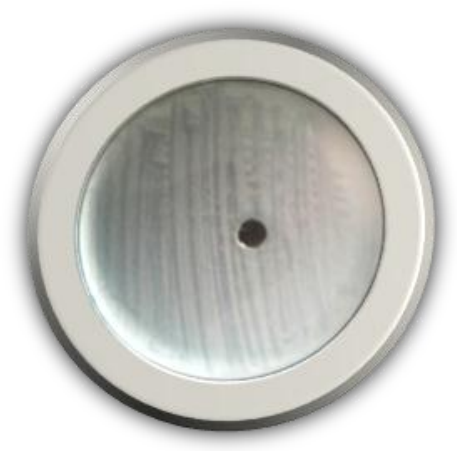

Candida krusei

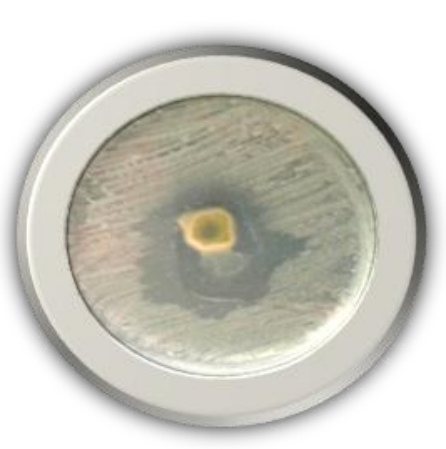

Candida glabrata

Fig. (13): Antifungal activities of ethanol extract of Hormophysa triqutra concentration $(100 \mathrm{mg} / \mathrm{ml})$ on oral Candida species growth.

The data in Figs. 14. 15 and 16 showed that:

i. Methanol extract of Hypnea cornuta showed an effect against Candida albicans, $C$. tropicalis and C. glabrata with inhibition zones of $28 \mathrm{~mm}, 30 \mathrm{~mm}$ and $32.67 \mathrm{~mm}$ (respectively). While it had no effect against $C$. krusei.

ii. Ethanol extract of Hypnea cornuta showed an effect against Candida albicans, $C$. krusei and C.glabrata with inhibition zones of $22.33 \mathrm{~mm}, 22 \mathrm{~mm}$ and $31.33 \mathrm{~mm}$ (respectively). While it had no effect on $C$. tropicalis.

iii. Chloroform, Hot water and Cold water extracts of Hypnea cornuta showed no effect against any of the tested oralCandida $s p$. 


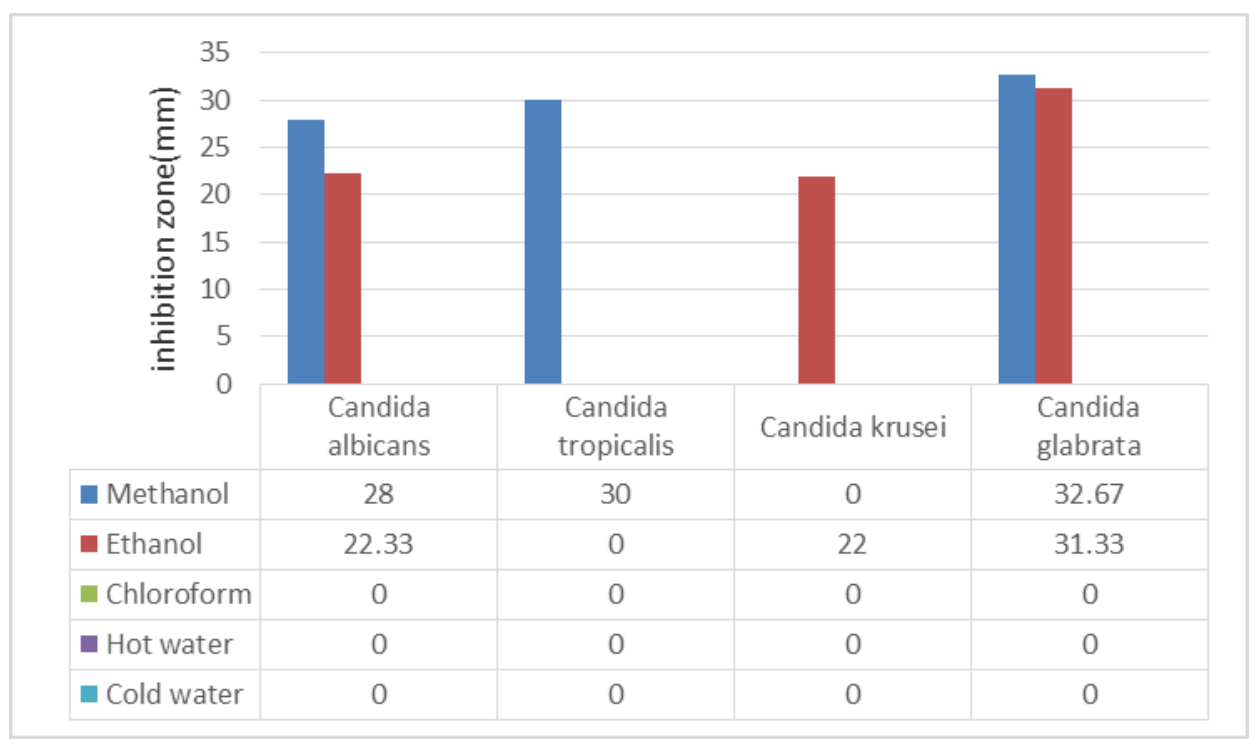

Fig. (14) : Antifungal activities of Hypnea cornuta extracts against oral Candida sp.

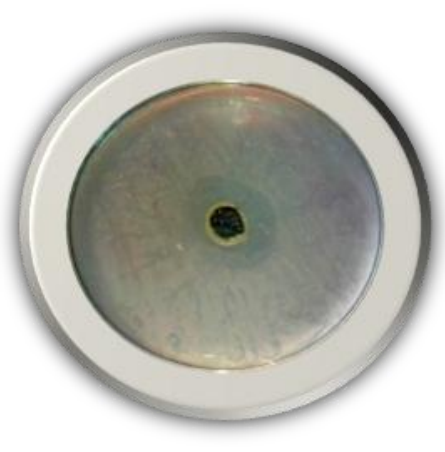

Candida albicans

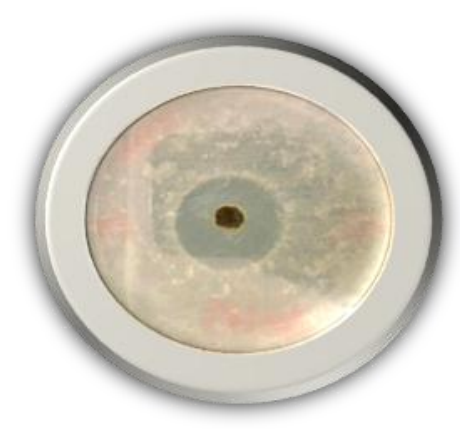

Candida tropical

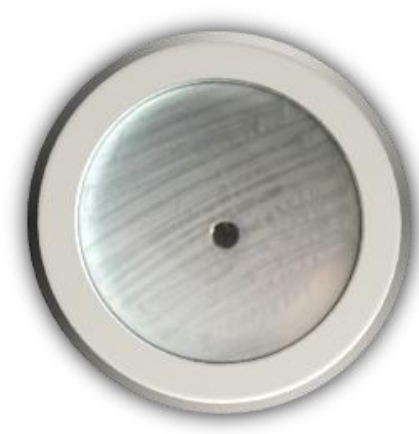

Candida krusei

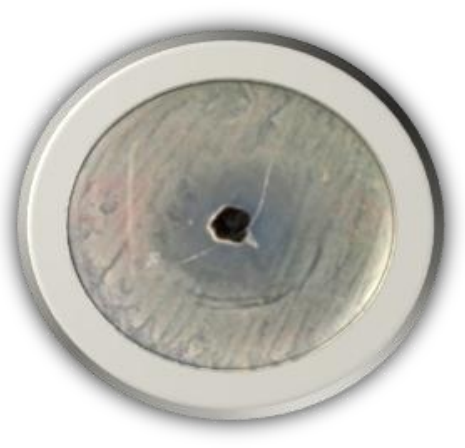

Candida glabrata

Fig. (15): Antifungal activities of methanol extract of Hypnea cornuta concentration $(100 \mathrm{mg} / \mathrm{ml})$ on oral Candida species growth

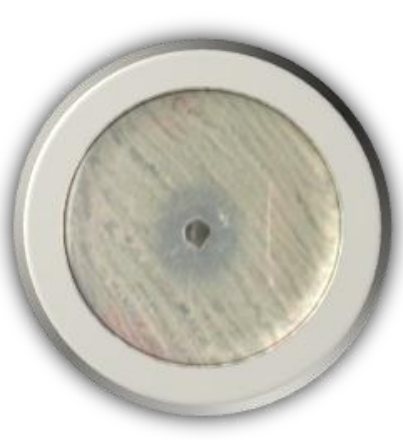

Candida albicans

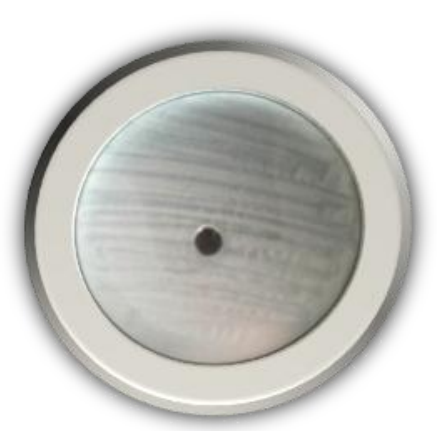

Candida tropicalis

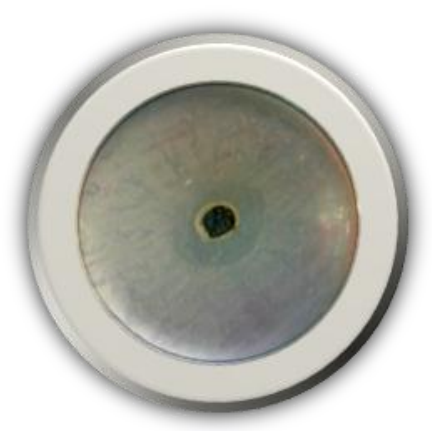

Candida krusei

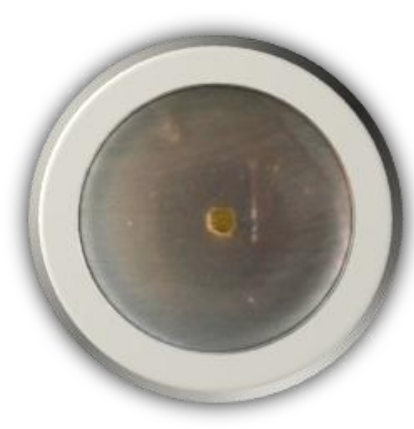

Candida glabrata

Fig. (16): Antifungal activities of ethanol extract of Hypnea cornuta concentration $(100 \mathrm{mg} / \mathrm{ml})$ on oral Candida species growth 


\section{Minimum Inhibitory Concentration (MIC) and Minimum Fungicidal Concentration (MFC):}

As shown in Fig.17 The MIC value of Ulva lactuca methanol extract was $62.5 \mathrm{mg} / \mathrm{ml}$ against all the tested oral Candida species, whereas the MIC value of ethanol extract was $62.5 \mathrm{mg} / \mathrm{ml}$ against Candida albicans, $C$. krusei and C. glabrata, but it had no activity against C. tropicalis. As well as the MIC value of chloroform extract was $62.5 \mathrm{mg} / \mathrm{ml}$ against Candida albicans, $C$. tropicalis and $C$. glabrata, but it had no activity against $C$. krusei. The extract by hot water and cold water had no activity against all the tested oral Candida $s p$.

Also as represented in Fig.18 The MFC value of Ulva lactuca methanol extract was 125 $\mathrm{mg} / \mathrm{ml}$ against all the tested oral Candida species, whereas the MFC value of ethanol extract was $125 \mathrm{mg} / \mathrm{ml}$ against Candida albicans and was $250 \mathrm{mg} / \mathrm{ml}$ against $C$. krusei and $C$. glabrata (independently), but it had no activity against $C$. tropicalis. As well as the MFC value of chloroform extract was $125 \mathrm{mg} / \mathrm{ml}$ against Candida albicans, $C$. tropicalis and $C$. glabrata (independently), but it had no activity against $C$. krusei. The MFC value of extracts by hot water and cold water had no activity against all the tested oral Candida species.

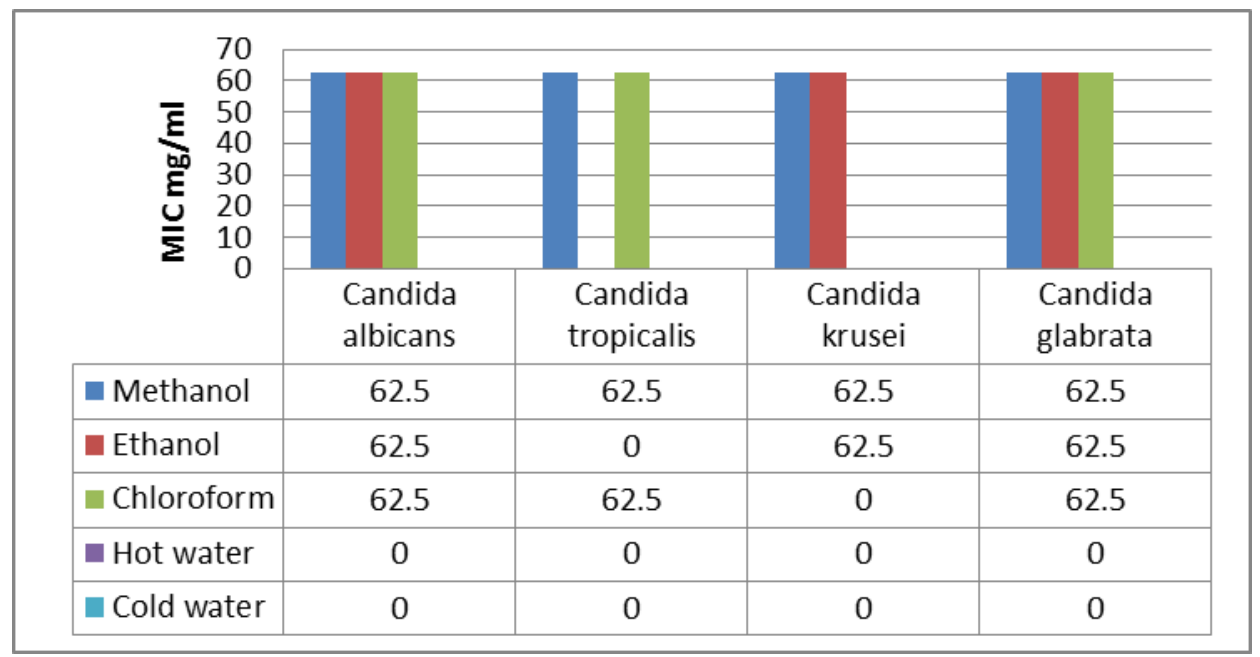

Fig. (17): Minimum Inhibition Concentration (MIC) $\mathrm{mg} / \mathrm{ml}$ of Ulva lactuca extracts against the tested oral Candida species.

\begin{tabular}{|c|c|c|c|c|}
\hline \multirow{6}{*}{$\begin{array}{r}300 \\
250 \\
200 \\
150 \\
100 \\
50\end{array}$} & & & & \\
\hline & \multirow[b]{5}{*}{$\begin{array}{l}\text { Candida } \\
\text { albicans }\end{array}$} & \multirow[b]{5}{*}{$\begin{array}{l}\text { Candida } \\
\text { tropicalis }\end{array}$} & \multirow[b]{5}{*}{$\begin{array}{c}\text { Candida } \\
\text { krusei }\end{array}$} & \multirow[b]{5}{*}{$\begin{array}{l}\text { Candida } \\
\text { glabrata }\end{array}$} \\
\hline & & & & \\
\hline & & & & \\
\hline & & & & \\
\hline & & & & \\
\hline Methanol & 125 & 125 & 125 & 125 \\
\hline Ethanol & 125 & 0 & 250 & 250 \\
\hline Chloroform & 125 & 125 & 0 & 125 \\
\hline Hot water & 0 & 0 & 0 & 0 \\
\hline Cold water & 0 & 0 & 0 & 0 \\
\hline
\end{tabular}


Fig. (18): Minimum Fungicidal Concentration (MFC) $\mathrm{mg} / \mathrm{ml}$ of Ulva lactuca extracts against the tested oral Candida species.

\section{Determination of the percentage inhibition of diameter growth (PIDG):}

Table (1): show the determination of the percentage inhibition of diameter growth (PIDG) for the tested oral Candida species. It revealed that the Ulva lactuca extract exhibited a higher inhibition ability compared to chlorhexidine(a positive control used in this study) which is a common antimicrobial agents in commercialized oral rinses.

Table (1): The percentage inhibition of diameter growth (PIDG):

\begin{tabular}{|c|c|c|c|c|c|}
\hline \multirow{2}{*}{ Isolates } & \multicolumn{3}{|c|}{ Diameter inhibition zone (mm) } & \multirow{2}{*}{ PIDG(\%) } \\
\cline { 2 - 5 } & Ulva lactuca extract & \multicolumn{2}{c|}{ Chlorhexidine } & \multirow{2}{*}{ DIZ } & \\
\cline { 2 - 5 } & MFC & DIZ & MFC & $11.33 \mathrm{~mm}$ & $44.48 \%$ \\
\hline Candida albicans & $125 \mathrm{mg} / \mathrm{ml}$ & $16.37 \mathrm{~mm}$ & $0.1 \mathrm{mg} / \mathrm{ml}$ & $13 \%$ \\
\hline Candida tropicalis & $125 \mathrm{mg} / \mathrm{ml}$ & $15.33 \mathrm{~mm}$ & $0.1 \mathrm{mg} / \mathrm{ml}$ & $13.33 \mathrm{~mm}$ & $15 \%$ \\
\hline Candida krusei & $125 \mathrm{mg} / \mathrm{ml}$ & $15 \mathrm{~mm}$ & $0.1 \mathrm{mg} / \mathrm{ml}$ & $12.33 \mathrm{~mm}$ & $21.65 \%$ \\
\hline Candida glabrata & $125 \mathrm{mg} / \mathrm{ml}$ & $16.33 \mathrm{~mm}$ & $0.1 \mathrm{mg} / \mathrm{ml}$ & $14 \mathrm{~mm}$ & $16.64 \%$ \\
\hline
\end{tabular}

\section{Discussion:}

Usage of commercial antibiotics for human disease treatment produces undesirable side effects. Cell extracts and active constituents of various algae may be potential bioactive compounds of interest in the pharmaceutical industry (Ely et al., 2004).

In the present study the results showed that the methanol extracts of the five tested algae (Spirulina platensis, Ulva lactuca, Sargassum denticulatum, Hormophysa triquetra and Hypnea cornuta) had the highest antifungal activity against the selected human pathogenic fungi (Candida albicans, C.tropicalis, C.krusei and C.glabrata) where as the highest values of inhibition zones for Sargassum denticulatum and Hormophysa triquetra methanol extracts against C.glabrata were of 55.33 and $40.33 \mathrm{~mm}$ (respectively).

These results were in agreement with that obtained by El-Sheekh et al. (2015)who found that the methanol extracts have the strongest inhibition against the tested microorganisms with inhibition activity percentage of $42.3 \%$, followed by ethanol extracts with inhibition activity percentage of $33.5 \%$. However ethyl acetate extracts have $14 \%$ inhibition activity, whereas chloroform showed the lowest inhibition activity percentage of $10.3 \%$ for all algae extracts against all tested fungi. Therefore, methanol was the best solvent for extractions. As well as, the results were in agreement with the results obtained by Pandian et al. (2011) who found that the tested petroleum-ether, chloroform and methanol of Acanthaphora spicifera in vitro for its antifungal activity against Candida albicans, 
Microsporum gypseum, Aspergillus niger, respectively by disc diffusion techniques. The methanol extract of Acanthaphora spicifera showed higher antibacterial and antifungal activity compared to the other two extracts. Also, the results were in harmony with the results obtained by Prabha et al. (2013) who found that the methanolic extract showed higher antimicrobial activity compared to ethanol and acetone. The methanol extract of Kappaphycus $d v a r e z i i$, the zone of inhibition was $6 \mathrm{~mm}$ against Micrococcus leutues, Escherichia Coli and Aspergillus flavus and 5mm against Staphylococcus aureus, Aspergillus fumigates and Candida albicans.

In addition, the results were cording with the results obtained by Sekar and Kolanjinathan(2015) who found that the crude methanolic extract of Padina gymnospora showed maximum mean zone of inhibition against Candida albicans $(15 \pm 09 \mathrm{~mm})$ followed by Turbinaria conoides $(15 \pm 09 \mathrm{~mm})$, Sargassum wightii $(15 \pm 0.5 \mathrm{~mm})$, Canlerpa racemosa $(12 \pm 0.8 \mathrm{~mm})$ and Acanthophora spicifera $(12 \pm 0.6 \mathrm{~mm})$ at $300 \mathrm{mg} / \mathrm{nl}$. The crude hexane extract of marine macroalgae showed minimum zone of inhibition against Candida albicans when compared to the other solvent extracts.

Methanol is a good solvent for extraction and it is frequently used in biology because of its high polarity . it is capable of extracting both lipophilic and hydrophilic molecules or substances. The other advantage is that it be removed easily at room temperature because it is highly volatile Fiedler et al.(2005).

In the present study the results showed that the green algae (Ulva lactuca) methanol extract was the most active against all the tested oral Candida species (Candida albicans, C.tropicalis, C.krusei and C.glaborata) with inhibition zones of 45,35,32 and 30mm (respectively). Followed by Phaeophyta, Rhodophyta and blue green algae, where they had similar effects against the tested oral Candida species.

These results were in agreement with that obtained by Osman et al. (2010) who found that the most active seaweeds was Ulva fasciata (Chlorophyceae) against all tested microorganisms (Bacillus subtitis, Staphylococcus aureusand streptococcus aureus as grampositive bacteria, and (Escherichia coli, Salmonella typhi and Klepsiella pneumonia as gramnegative bacteria) and one yeast strain Candida albicans. Followed by Rhodophyta and phosophyta. Also, the present results were in agreement with the results obtained by Kandhasamy and Arunachalam (2008) who reported that the Chlorophyceae showed high antimicrobial activity than other of the tested algae (Rhedophyceae and Phaeophycaea).

As well as, the present results were in agreement with the results obtained by Sheikh et al. (2018) who found that the Chlorophyta exhibited the highest antimycetic effect against Candida albican, C.tropicalis, Aspergillus flavus,

A. funmigatus and A. niger followed by Rhodophyta and Phaeophyta.

The reason for the convergence of these results were the similarity of the environmental conditions to which algae have been exposed.

In the present study the results showed that the Ulva lactuca methanol extract was active against all the tested oral Candida species with the MIC and MFC of 62.5 and 125 $\mathrm{mg} / \mathrm{ml}$, Whereas the Ulva lactuca ethanol extract was active against Candida albicans, C.krusei and C.glabrata with the MIC and MFC of 62.5 and $125-250 \mathrm{mg} / \mathrm{ml}$ (respectively). Also Ulva lactuca chloroform extract was active against Candida albicans, C.tropicalis and 
C.gabrata with the MIC and MFC of 62.5 and $125 \mathrm{mg} / \mathrm{ml}$. In general the values of MFC were higher than the corresponding values of MIC.

These results were in agreement with that obtained by Saleh andAl-Mariri (2018) who reported that the methanolic Sargassum vulgare extract was the strongest by showing the lowest MIC value of 0.11 and $0.133 \mathrm{mg} / \mathrm{ml}^{-1}$ against Aspergillus nigher and Candida albicans, (respectively) and the lowest MFC value of $1.67 \mathrm{mg} / \mathrm{ml}^{-1}$ for the broth fungal strains. Also, the results were in agreement with the results obtained by Saleh and Al-Mariri (2017) who reported the inhibitory effect of Ulva lactuca (Chlorophyta), Dilophusspiralis (Phaeophyta) and Jania rubens (Rhodophyta) marine seaweeds against 2 fungal (Candida albicans and Aspergillus niger straine using aqueous and six organic extracts. The previous investigation showed that the lowest MIC value was recorded to be $0.106 \mathrm{mg} / \mathrm{ml}^{-1}$ with Ulva lactuca methanolic extract against broth fungal strains and with acetone and hexane against Candida albicans moreover, the lowest MFC value $\left(0.266 \mathrm{mg} / \mathrm{ml}^{-1}\right)$ was observed with Dilophus spiralis chloroform against broth fungal strains.

Moreover, Kim et al. (2014) recorded antifungal activity of ethyl acetate edible brown seaweed Eisenia bicyclis extract against Candida species. The previous investigation showed that MIC/MFC values ranged between 4-32/16-64 mg/ml ${ }^{-1}$ against Candida albicans, overall, ethyl acetate. Soluble extract was the most potent with MIC/MFC values ranged between 4$8 / 16 \mathrm{mg} / \mathrm{ml}^{-1}$ against the tested strain.

In the present study the results showed that the percentage inhibition of diameter growth (PIDG) for the tested oral Candida species (Candida albicans, C.tropicalis, C.krusei and C.glabrata). It revealed that the Ulva lactuca extract exhibited a higher inhibition ability compared with chlorhexidine (a positive control used in this study) which is a common antimicrobial agents in commercialized oral rinses. Based on the percentage, Candida albicans was highly affected (44.48\%) followed by C.krusei (21.65\%), C.glabrata (16.64\%) and C.tropicalis (15\%). Since the present study was the first to conducte this PIDG test on algae extracts.

So the present results will be compared with that obtained by Himratul-Aznita et al. (2011) and Nordin et al., (2013) who used the PIDG test on higher plants.

These results were in agreement with that obtained by Himratul-Aznita et al. (2011) who found that the percentage inhibition of diameter growth (PIDG) of Piper betle crude aqueous extract against oral candida species ( Candida albicans, C.tropicalis, C.krusei, C.lusitaniae, C.dubliniensis, C.glabrata and C.parapsilosis ), was exhibited a higher inhibition ability compared to chlorhexidine, were the PIDG values for Candida albicans, C.tropicalis, C.lusitaniae, C.dubliniensis and C.glabrata has shown that the aqueous extract of Piper betle outstrips the positive control used, that was $0.12 \% \mathrm{w} / \mathrm{v}$ chlorhexidine with PIDG values of more than $50 \%$ at Piper betle concentration of $25 \mathrm{mg} / \mathrm{ml}$. In contrast, PIDG for C. krusei and C.parapsilosis Shown that at $25 \mathrm{mg} / \mathrm{ml}$ concentration of Piper betle extract has little influence on growth inhibition compared to chlorhexidine. Thus, the results obtained have shown the potential use of Piper betle extract as antifungal agent and thus significantly contribute to its antifungal development. as well as, the results were in agreement with that obtained by Nordin et al., (2013) who found that the determination PIDG for Brucea javanica extract compared with chlorhexidine. Based on the percentage, Candida glabrata and C. dubliniensis and followed by

C. lusitaniae were highly affected by 
the extract of Brucea javanica which outstrips the chlorhexidine (positive control). The PIDG for $C$. albicans however outstrips the positive control at high concentration of $200 \mathrm{mg} / \mathrm{ml}$, suggesting that the effectiveness of the extract on each Candida cell was dose-dependent. The other Candida species were less affected by the control and this explains the effectiveness of CHX as a reference in many clinical trials.

The reason for the convergence of these results were the algal extract contain compounds such as carbohydrates, proteins, minerals, oil, fats, polyunsaturated fatty acids as well as bioactive compounds such as antioxidants (polyphenols, tocopherols, vitamin E, vitamin C. mycosporine-like amino acids) and pigments, such as carotenoids (carotene xanthophylls) cholorophylls, and phycobilins (phycocyanin, phycoerythrin), which possess antibacterial, antiviral, antifungal, antioxidative, anti-inflammatoryand antitumor properties.

\section{Conclusion:}

The results proved the promising antifungal potency of the used solvent extracts for some algae Chlorophyta (Ulva lactuca), Phaeophyta (Sargassum denticulatum, Hormophysa triquetra) and Rhodophyta (Hypnea cornuta) from North-east of the Gulf of-Suez and the Red Sea coast, Egypt.in addition to one blue- green alga from freshwater (Spirulina platensis) was obtained from stock at Hydrobiology Lab, Qanater, Khayria, Qalubia, Egypt. It has been suggested that the active antifungal compounds in seaweeds were found to be interesting. Thus exploration of such biological agents might be a probable resource of an array of biologically active compounds and the present results will ensure a starting point for exploiting natural bioactive substances presents in the extracts of marine algae. Such compounds may serve as leads in the development of new pharmaceuticals. Consequently, our future research direction is toward isolation, purification and identification of the bioactive ingredients to understand their bio prospects.

\section{References:}

Aggarual, N.; Bhateja, S.; Arora, G. and Yasmin, T. (2018). Candidiasis. The most common fungal infection of oral cavity. Biomedical Journal of Scientitic and Technical Research, (1-5).

Bauer, A.W.M.; Kirby, M.; Sherris, C. and Truck, M. (1996). Antibiotic susceptibility testing by a standardized single disc method. American Journal of Clinical Pathology; 45(4): 493-496.

Bellinger, E.G. and Sigee, D.C.(2015). Freash water algae identification, enumeration and use as bioindicators. ISBN. 978-1-118-91716-9 (hard book)

Bhakuni, D.S. and Rawat, D.S. (2005). Bioactive marine natural products. New Delki, p. 103-124.

Blunt, J.W.; Carroll, A.R.; Copp, B.R.; Davis, R.A.; Keyzers, R.A. and Prinsep, M.R. (2006). Marine natural products. Natural Product Report, Londres, B. 23, p. 26-78.

Cho, S.k.; Kang, S.E.; Cho, J.; Kim, A.; Park, S.; Hong, Y. and Ahn, D. (2007). The antioxidant properties of brown seaweed (Sargassumsiliquastrum) extracts. J. Med. Food. 10(3): 479-485. 
Clinical and Laboratory Standards Institute (2002). Reference method for broth dilution antifungal susceptibility testing of yeasts: approved standard-second edition. Wayne : Clinical and Laboratory Standards Institute, P. 51.

El-bashiti, T.R.; Elmanama, A.A. and Masad, A.A. (2011). The antibacterial and synergistic effects of some Palestinian plant extracts on Escherichia coli and Staphylococcus aureus. Functional plant science and Biotechnology, (57-62).

El-Sheekh, M.M.; El-Shafay, S.M. and El-Ballat, E.M. (2015). Production and characterization of antifungal active substance from some marine and freshwater algae. International Journal of Environmental Science and Engineering (IJESE), 6:85-92.

Ely, R.; Supriya, T. and Naik, C.G. (2004). Antimicrobial activity of marine organisms collected of the coast of south East India. Journal of experimental marine biology and ecology, 309(1), 121-127.

Fiedler, E.G.; Grossmann, D.; Burkhard, K.G.; Weiss, C. and Witte. (2005). "Methanol". Ullmann's Encyclopedia of Industrial Chemistry. Ullmann's Encyclopedia of Industrial Chemistry. Weinheim: Wiley VCH. doi:10.1002/ 14356007.a16_465. ISBN 978-3527306732

Greenberg, M.S. and Burker's, G.M. (2005). Oral Medicine Red and White Lesions of the oral cavity.Delhi, India, BC. Decker Inc, Elsevier, pp (85-125).

Harun, R.; Yip, J.W.S.; Thiruven Kadam, S.; Ghani, W.A.K. (2014). Algal biomass conversion to bioethanol. A step. By step assessment Biotechniol, 9, 73-86.

Himratal-Aznita, W.H.; Mohd-Al-Faisal, N. and Fathilah, A.R. (2011). Determination of the percentage inhibition of diameter growth (PIDG) of Piper betle crude aqueous extract against oral Candida species. Journal of Medicinal Plants Research, 5(6) : 878-884.

Kandhasamy, M. and Arunachalam, K.D. (2008). Evaluation of in vitro antibacterial property of sea weeds of southwest coast of India. African Journal of Biotechnology, 7(12): 1959-1961.

Karabay-Yavasoglu N.U, Sukatar A, Ozdemir G and Horzum Z (2007). Antimicrobial Activity of Volatile Components and Various Extracts of the Red Alga Janiarubens. Phytother. Res., 21: 153-156.

Kim, K.H.; Eom, S.H.; Kim, H.J.; Lee, D.S. and Nshimlyumukiza, O. (2014). Antifungal and synergistic effects of an ethyl acetate extract of the edible brown seaweed Elseniabiculis against Candida species. Fish Aquat. Sci., 17:209-214.

Machado, F.L.D.S.; Kaiser, C.R.; Costa, S.S.; Gestinari, L.M. and Soares, A.R. (2010). Atividade biologica de metabolites Secundarios de algas marinhas do genero laurenica. Brazilian Journal of pharmacognosy, (3) 441-452.

Michalalk, I. and Chojnacka, K. (2014). Algal extracts: technology and advances. Engineering in life sciences, 14, 581-591. 
Misra, S.B. and Dixit, S.N. (1978). Antifungal properties of leaf extract of Ranunculus sceleratus L. Experientia, 34: 1442-1443.

NCCLS. (2002). Methods for dilution antimicrobial susceptibility tests for bacteria that grow aerobically. Approved Standard ${ }^{\text {rd }}$ ed. NCCLS document M100-S12. Wayne, PA, National Committee for Clinical Laboratory Standards.

Nordin, M.A.; Wa Haran, W.H. and Abdul Razak, F. (2013). Antifungal susceptibility of growth inhibitory response of oral Candida species to Brucea javanica Linn. Extract. BMC complement Altern Med, (131:342).

Osman, M.E.; Abushady, A.M. and Elshobary, M.E. (2010). In vitro screening of antimicrobial activity of extracts of some macroalgae collectivity from Abu-Qir bay Alexandria, Egypt. African Journal of Biotechnology, 9(12): 7203-7208.

Pandian, P.; Selvamuthukumar, S.; Manavalan, R. and Parthasarthy, V. (2011). Screening of antibacterial and antifungal activities of red marine algae Acanthaphora spicifera (Rhodophyceae), Biomed scientitic Research, 3: (444-448).

Papenfuss, G.F. (1989): A history, catalogue and bibliography of Red Sea benthic algae. Israel Journal of Botany. 17,1-2.

Prabha, V.; Prakash, D.J. and Sudha, P.N. (2013). Analysis of bioactive compounds and antimicrobial activity of marine algae Kappaphycus alvarezii using three solvents extracts. International Journal of Pharmaceutical sciences and research, 4(1) : 306310.

Saleh, B. and Al-Marriri, A. (2018). Antifungal activity of crude seaweed extracts collected from latakia coast, Syria, Journal of fisheries and Aquatic Science., 13:49-55.

Saleh, B. and Al-Mariri, A. (2017). Antimicrobial activity of the marine algal extracts against selected pathogens. J. Agric. Sci. Technol., 19:1067-1077.

Sekar, D. and Kolanjinathan, K. (2015). Screening of antifungal activity of selected macroalgae against Candida albicans and Candida glabrata. Indo-Asian Journal of Multidisciplinary Research, (325-319).

Sheikh, H.; El-Naggar, A. and Al-Sobahi, D. (2018). Evaluation of antimycotic activity of extracts of marine algae collected from Red Sea coast, Jaddah, Saudi Arabia. Journal of Biosciences and Medicines, 6, 51-68.

Shobier, A.H.; Abdel Ghani, S.A. and Barakat, K.M. (2016). GC/MS spectroscopic approach and antifungal potential of bioactive extracts produced by marine macroalgae. Egyptian Journal of Aquatic Research, 42, 289-299.

Smit, A.J. (2004). Medicinal and pharmaceutical uses of seaweed natural products : A review. Journal of Applied Phycology, Dordrecht, V. 16, p. 245-262.

Subash, A.; Hanumantha, R.B.R. and Adoor, G.S. (2010). In vitro antioxidant and in vivo anti inflammatory potential of crude polysaccharide from tubinaria ornate (Marine Brown Alga), food ChemToxicol,48(1),187-192. 


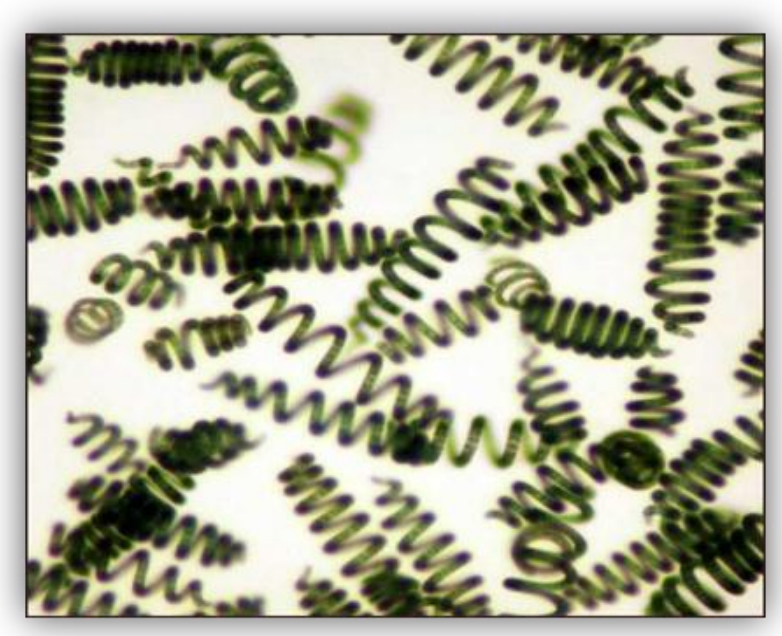

Spirulina platensis (Nords) $\quad .40 \mathrm{X}$

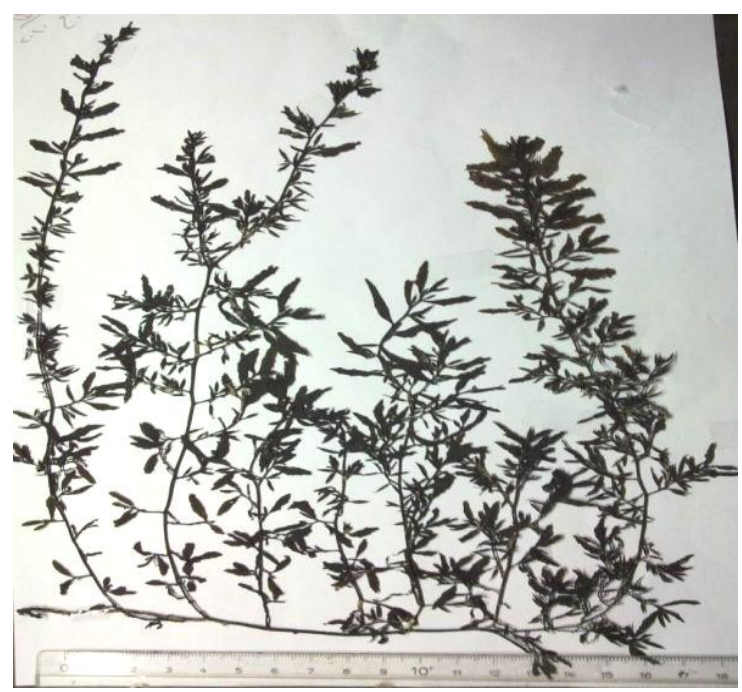

Sargassum denticulatum (BØrgesen). $10 \mathrm{~cm}$

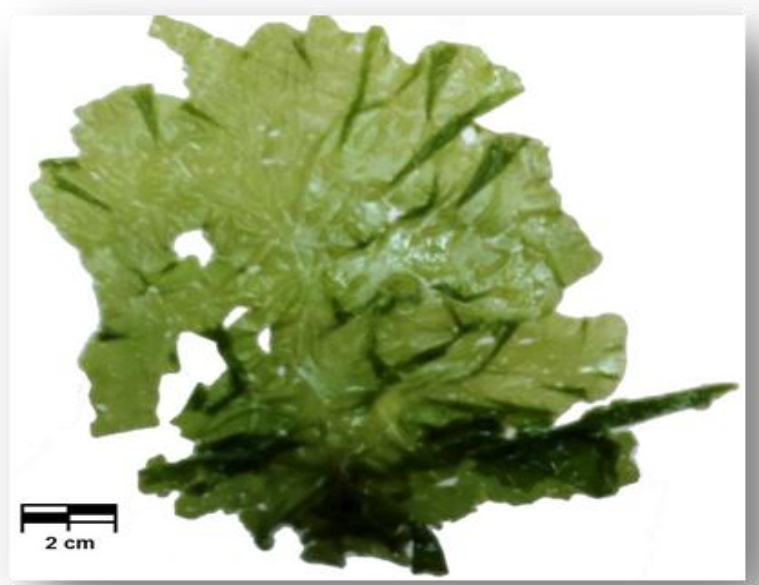

Ulva lactuca (Linnaeus). $2 \mathrm{~cm}$

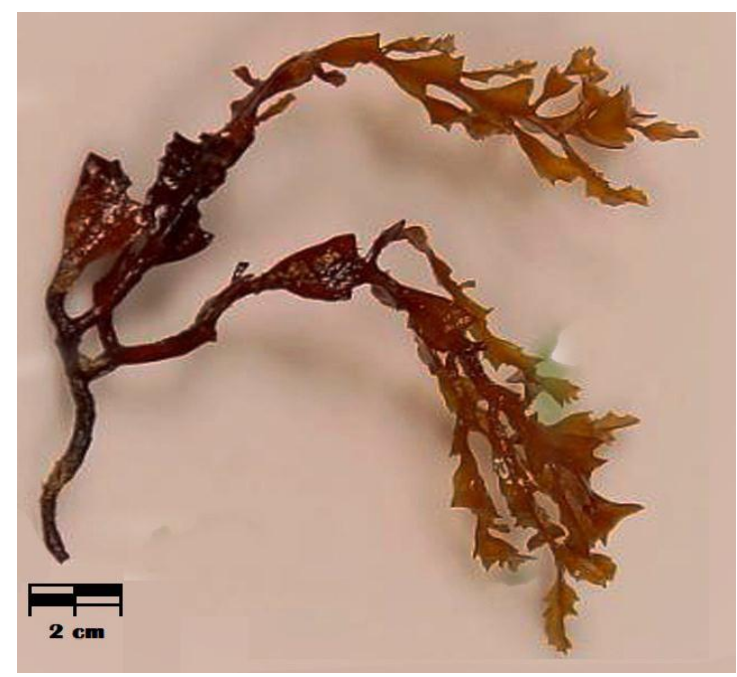

Hormophysa triquetra ( Kütizing). $2 \mathrm{~cm}$

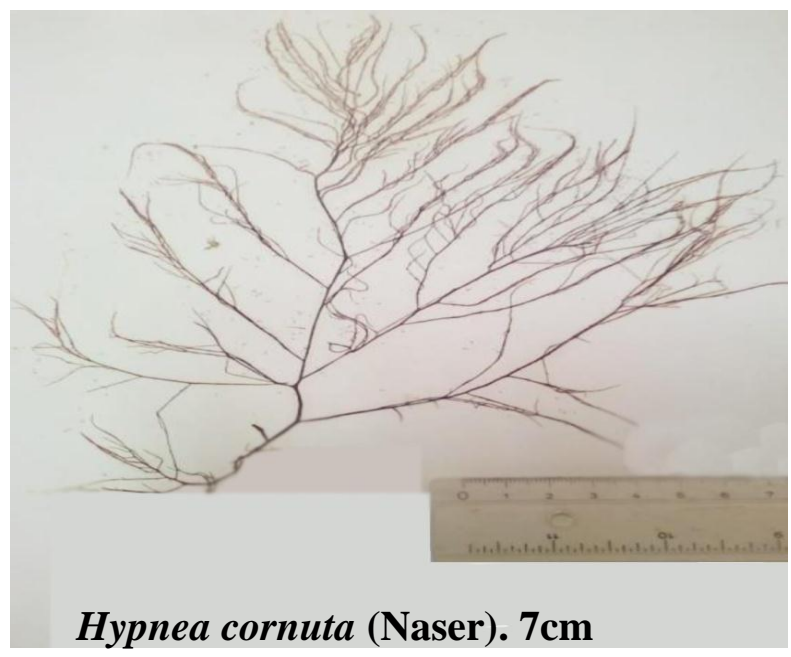




\section{فحص الانشطة المضادة للفظريات لخمسة مستخلصات خام من الطحالب}

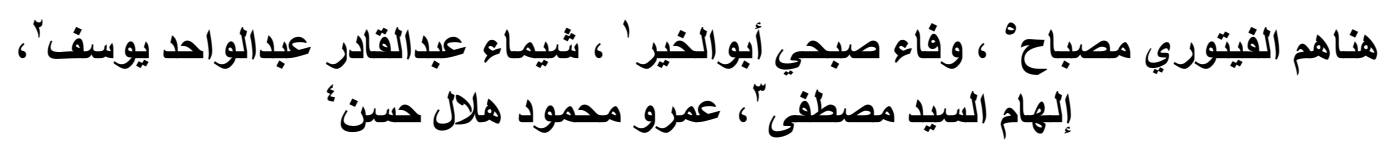

$$
\begin{aligned}
& 1 \text { أستاذ علم الطحالب، قسم النبات، كلية البنات للآداب و العلوم و التربية، جامعة عين شمس. } \\
& \text { r مدرس علم الطحالب، قسم النبات، كلية البنات للآداب و العلوم و التربية، جامعة ولئة عين شمس. } \\
& \text { r مدرس ميكروبيولوجي، قسم النبات، كلية البنات للآداب و العلوم و التربية، جامعة عين شمس. } \\
& \text { ع باحث في المعهد القومي لعلوم البحار و المصايد. }
\end{aligned}
$$

في هذه الدراسة تم جمع أربعة أنواع من الطحالب البحرية خلال مواسم مختلفة لمدة عام واحد

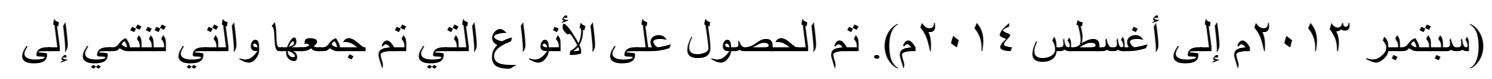

Chlorophyta (Ulva lactuca), Phaeophyta (Sargassum denticulatum, Hormophysa

triquetra) and Rhodophyta (Hypnea cornuta)

بالإضافة إلى طحلب Blue green algae من المياه العذبة (Spirulina platensis). تم الحصول عليه من مختبر القليوبية مصر. تم تحضير مستخلصات الطحالب الخام باستخدام مذيبات مختلفة (الميثانول والإيثانول والكلوروفورم) بالإضافة إلى طريقة الاستخلاص بالماء الساخن والماء البارد. تم فحص مستخلصات الطحالب الخام لفعاليتها المضادة للفطريات ضد أنواع المبيضات الفموية

(Candida albicans, Candida tropicalis, Candida krusei and Candida glabrata)

باستخدام طريقة انتشار الآغار. أظهرت النتائج أن الميثانول هو أفضل مذيب مناسب لاستخر اج المركبات النشطة حيوياً من الطحالب المختبرة. عرضت Chlorophyta (Ulva lactuca) أعلى تأثنير مضاد للفطريات يليه Rhodophyta Phaeophyta وطحلب Blue green. كان أدنى تركيز مثبط (MIC) لمستخلصات الطحالب الأكثر فاعلية (Ulva lactuca) مستخلص الميثانول ه.ب ملغ/مل وكان الحد الأدنى لتركيز مبيدات الفطريات(MFC) م ا ملجم / مل لنفس الطحلب مع جميع أنواع المبيضات الفموية التي تم اختبار ها. تم إجراء مقارنة بين قيمة MFC لمستخلص الميثانول أولفا لاكتوكا مع مضادات الكلور هيكسيدين ( 1 . · ملجم / مل (و هو مضاد تجاري شائع للميكروبات لشطف الفم) باستخدام طريقة النسبة المئوية لتثبيط نمو القطر (PIDG) ضد أنواع المبيضات الفموية المختبرة. أوضحت النتائج أن مستخلص ميثانول أولفا لاكتوكا كان الأفضل بالنسبة ل PIDG من الكلور هيكسيدين (مضاد حيوي 